\title{
Swift's Switch: The Intricacies of Turning
}

\section{Tory ${ }^{1}$}

\section{Steven Scott}

ABSTRACT: Jonathan Swift is widely recognized as a major writer in English. His Gulliver's Travels, $A$ Tale of a Tub, and "A Modest Proposal," in particular, are masterpieces of political satire. Swift was never a politician in his own right, but the politics of his writing and his role as a politically committed priest in the Irish Anglican Church made him important nonetheless as a political and historical figure. In fact, for a time in the early eighteenth century. Swift truly became a part of English politics, first by negotiating with the English government on the part of the Irish Church, and then by beginning to write political propaganda for the Tory regime then in power. Near the end of 1710, Jonathan Swift changed his political allegiance from Whig to Tory. This paper discusses the four major explanations that have been advanced regarding Swift's "switch." and suggests that none of the four is adequate, though all of them contain elements of what is likely to have happened. It suggests, further, that Swift's switch was at least as much a result of the changing nature of political parties and the party system as inconsistency on Swift's part.

Jonathan Swift, a Church of Ireland clergyman and a literary figure whose fame continues to this day, arrived in London from Dublin on 2 September 1710 . He was intent on renewing his negotiations with the British government for the remittance of the "First Fruits" - a stipend enjoyed by the English clergy from feudal times - and "Twentieth Parts" - the remission of a traditional tax on clergy benifices - on behalf of the Irish Anglican Church. ${ }^{2}$ Swift's first task in London was to garner all the political backing he could muster. He began immediately to visit influential friends and acquaintances, most of them Whigs. ${ }^{3}$ By the end of September, however, Swift grew impatient with his Whig associates, who were more concerned with the rumoured overthrow of Godolphin's predominantly Whig government than with his mission to secure "Bounty" for the Irish Church. ${ }^{4} \mathrm{He}$ met first with new Tory Parliament leader Robert Harley ar the beginning of October, and was "represented to Harley as a discontented person, that was used ill for not being Whig enough." By the beginning of November, Swift was in charge of the chief Tory propaganda newspaper, the Examiner. During Swiff's two-month stay in London, he changed from an apparently commitred Whig to the Tories' top propagandist. W.A. Speck has claimed

Past Imperfect, Vol. 2, 1993, pp. 107-121 
that "this change is the key to Swift's politics," and that "if we could explain it we would solve the knottiest problem of his political allegiance, for he never changed again."

There have been four main theories advanced to explain Swift's sudden conversion to the Tory cause. The first portrays Swift as a selfish place-seeker who changed parties for personal gain. The second depicts him as a virtuous man of principle who became Tory out of conviction. The third stresses Swift's desire for revenge on the Whigs for perceived ill-treatment. The fourth claims he did not really change parties at all. When Swift arrived in London, he encountered a Whig party that was far more organized than the Tories'. Swift helped to pull rogether a Tory party that Geoffrey Holmes has described as "a confederacy very much looser than that which held the Whigs together. ${ }^{n 7}$ The Tories' newfound cohesion was accomplished in part in the pages of the Examiner. The changing nature of "party" is at the heart of Swift's change, and the reason Swift "never changed again."

D.H. Stevens is represencative of those who have portrayed Swift as entirely self-interested when he changed from Whig to Tory. "Of all the writers then in England," writes Stevens, "he was most keenly alive to the possibilities of his age, and probably no one was more ready to ignore political beliefs for the sake of immediate advantage...

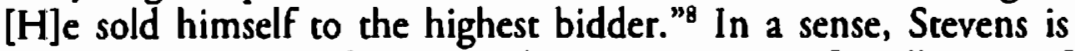
precisely correct. Preferment and patronage were, after all, parts of a system that in its own context was neither good nor evil, but merely a reality of the time period. Indeed, Swift was no fool, making liberal use of preferment. He gained all his early church appointments through patronage. The deanery where he lived out his bitter last years was provided through similar channels. In addition, his mission on behalf of the Irish Church presumed the legitimacy of preferment. The evidence is compelling, and Stevens's case is convincing, but Swift benefited very little personally from his change in party. Louis Landa suggests that Swift's ambition was for "a benefice in the Anglican Church in England," a prize "which eluded him even at the height of his power and influence" as chief Tory propagandist." If Swift really sold himself as Stevens suggests, he appears to have made a bad bargain. Stevens's theory also does not address Swift's failure to switch back to the Whigs when Harley's Tory regime fell out of favour. Surely a man "ready to ignore political beliefs for the sake of immediate advantage" would not have hesitated, in the face of what he felt was Tory neglect, to rejoin the Whigs. 
There is considerable evidence to support a claim that Swift was a man of principle. For instance, during Swift's negotiations in 17089 with Godolphin for Queen Anne's Bounty for the Irish Church, he flatly refused to negotiate political or religious beliefs. Godolphin had asked the Irish Church to give up its position on the Sacramental Test Act in exchange for the Bounty, and the talks stalled when Swift declined. ${ }^{10}$ Swift himself claimed to have acted honourably in his negotiations in 1710, and in his decision to change party: "I endeavour to act in the most exact points of honour and conscience, and my nearest friends will not understand it so." " Even if Swift was a man of principle, however, he was not the saint Thomas Sheridan described: "[Swift] had long formed in his head some great plan for promoting the publick welfare, in regard to which all considerations of self, weighed but as the dust upon the balance." 12 It is difficult to reconcile Sheridan's selfless philanthropist with Swift's self-congratulation over the success of his personal influence on Harley.

John Middleton Murry does not address preferment at all, but argues that Swift changed party out of revenge. Murry suggests that "[m]uch of the peculiar satisfaction he derived from his brilliant work for the Tories was that it showed the Whig grandees what a mighty mistake they had made in not treating him as an equal. ${ }^{{ }^{1 / 4}}$ Swift's Journal to Stella abounds with supporting references for Murry's thesis. For instance, on 10 September 1710, after a frustrating meeting with Godolphin, he wrote: "I am come home rolling resentments in my mind, and framing schemes of revenge."1s Swift may have wanted revenge, and may have changed party in order to exact it, but Murry's thesis supposes an inconsistency in Swift. He became very bitter toward Harley and St. John for the way they had treated him, although he never "vowed revenge" on them. ${ }^{16}$

Irvin Ehrenpreis is one of the critics who claims that Swift did not really change parties at all. "If I ... refuse to classify Swift among the Whigs during those years, my reason is that he showed no sympathy with the tenets peculiar to their cluster of factions and made no gesture to support them. ${ }^{\text {"17 }}$ Ehrenpreis's argument essentially amounts to apologetics. He does not explain, for instance, why Swift classified himself as such. "[I]t was in 1702," writes Swift, "that I first began to trouble myself with the difference between ... Whig and Tory ... [and] found myself to be what they called a Whig in politics."18 Ehrenpreis also ignores numerous references in the Journal to Stella of Harley being ready to "do every thing to bring me over." 19 
Kathleen Williams proposes a somewhat more useful interpretation of the theory that Swift did not change party. She wishes to establish Swift as a master compromiser in what she calls an "Age of Compromise." For Williams, Swift's position remained constant: he was always both a Tory who hated the notion of Jacobitism, and a Whig who hated dissent. The apparent change in loyalty in Swift amounts to empty party rhetoric. Speck has little time for Williams's argument, and his response to her work is terse: Swift was an extremist, he notes, not a moderate. ${ }^{20}$ Swif's views were indeed not moderate. They were un-compromising as far as both Church and State were concerned. In "The Sentiments of a Church of England Man," for instance, Swift wrote: "I should think that, in order to preserve the Constitution entire in Church and State; whoever hath a true value for both, would be sure to avoid the Extreams of Whig for the sake of the former, and the Extreams of Tory on account of the latter." ${ }^{21}$ Swift may at first sound moderate in this quotation. Both "extreams," however, are merely positions that disagree with Swift's. For the Whigs, extremism included Protestant Dissent, and for the Tories, it meant obedience to the principles of Divine Rights. ${ }^{22}$ Swift passionately and immoderately attacked both positions in his published writings, yet he did not avoid extremes to do so. Surely the Whig toleration of dissent is the moderate position. Instead of remaining truly moderate, Swift became the Tories' chief propagandist.

W.A. Speck's version of the view that Swift remained true to his own principles throughout his career is the most engaging. Speck names Swift's early personal connections to William Temple as primarily responsible for his early foray into the world of the Whigs and his personal connections to Harley as "crucial" to his conversion to the Tory camp. In other words, Swift's sympathies were not with party at all, but with friends. Speck's argument is compelling. The single most significant objection to it is the way Swift treated his Whig friends after he "converted" to the Tory cause. If Swift can be portrayed as a loyal, determined friend first, and political party member second, then why did his friendships with prominent Whigs end so abruptly in $1710 ?^{23}$ For that matter, if Swift was such a "determined" friend, why was he so willing to slander prominent Whigs, some of them former friends, in the pages of the Examiner? ? $^{24}$

In spite of their failings, each version of Swift's "switch" has elements of the cruth in it. It is true that Swift used preferment for his own ends, even while he negotiated for the good of the Church. 
He also tried, while using preferment, to act in good conscience, for he seems to have believed in the causes he supported. There was an element of revenge involved in his work in the Examiner. He did, in fact, feel that the Whigs had treated him badly. They had, but so did the Tories, and so did the Church. Powerful men, such as Temple, Harley, Pope, influenced Swift throughout his life. Harley's personal influence should not be underestimated. Swift talks often about his "personal credit" with Harley, who was, claims Geoffrey Holmes, "in many ways ... the key political figure of the whole period from 1695 to $1714 . " 25$

The entries in the Journal to Stella regarding Swift's negotiations with the Whigs are celling. Swift wrote that several of the Whigs were "ravished to see me," although Godolphin "received me with a great deal of coldness." Swift complained constantly of Whig "baseness and ingratitude," and of his ill usage "for not being Whig enough." ${ }^{26}$ The tone of these entries is entirely personal, for Swift tried to make use of his own influence, to bring to bear what power he had in the political circles he knew. And his political circles were also his social circles. His discussions usually took place in coffee houses, among friends, and over dinner. For Swift, newly arrived in London in Seprember, 1710, politics had not changed significantly from the days when he had petitioned King William for a position in the Church, "upon the Claym of a Promise his Majesty had made to Sir WT. ${ }^{n 27}$ And Swift's initial negotiations with Harley were carried out in the same terms. Swift wrote about his budding friendship with Harley. He described conversations over dinner dinners, chatted about time spent in coffee houses, and when the First Fruits were granted, the task was assumed to be "purely done by my personal credit with Mr. Harley." 28

During the time period that Swift was conducting his negotiations, the political world shifted. ${ }^{29}$ Swift found, to his dismay, that the Whigs, as the party in power, had begun to focus primarily on politics. ${ }^{30}$ Already, in 1709 , Godolphin had proven unwilling to be swayed by personal interests or friendship. Queen Anne's Bounty would be granted only at the cost of the Test Act. The Tories soon followed suit. Although Swift wrote that Harley was willing to petition Anne for the granting of the Queen's Bounty on the basis of "personal credit," that credit was soon paid in political coin. Swift took over the Examinerin return for Harley's influence. The political realities of "Mr. Examiner's" London were not the political realities 


\section{Past Imperfect}

of Sir William Temple's London. And the confusion about Swift's change in party in 1710 arose from a failure to take those differences seriously. The rise of the party system coincided with a growth in literacy, and a corresponding burgeoning use of the possibilities of propaganda. ${ }^{31}$ Swift's Examiner played a vital role in delineating a coherent position, a party position, for the Tories.

When Swift took over as editor of the Examinerin the fall of 1710, the journal had several roles to fulfil. First, the Examiner disseminated party policy. The Examiner had been created "to serve the [purposes] of Robert Harley" 32 by "molding public opinion for particular political ends. ${ }^{n 3}$ In Examiner Number 15, for instance, Swift wrote: "Considering the many grievous Misrepresentations of Persons and Things, it is highly requisite, at this juncture, that the People throughout the Kingdom, should, if possible, be set right in their Opinions by some impartial Hand; which hath never been yet attempted..." ${ }^{34}$ Swift proposed to be a non-partisan, impartial "Examiner" of English politics by writing Tory propaganda. If Kenyon is correct, and "conservatism was the Englishman's natural political philosophy," 35 the Examiner helped to formalize that natural inclination into policy and dogma.

A second role of the Examinerwas to articulate, print, and thereby validate party policy for Tory members of parliament, and, more generally, for the country gentlemen who elected them. ${ }^{36}$ When Harley seized power in 1710, the Tories needed to become, and then to appear, as a coherent, viable political force. ${ }^{37}$ The Examiner was the vehicle chosen to accomplish that end. The issues addressed in Swift's first Examiner included the problem of rigid party lines, the virtues of loyalty to the Queen (and of respecting her wise choice in the new ministry), the problem of continuing a war which would only benefit a minority, the necessity of loyalty to the Church, the high taxes in the kingdom, and the shift in power from landed to monied interests. The first issue decailed the principles of the new Examiner, and identified them as the principles of Harley, of the Tory party newly in power, and supposedly of the Queen and the nation as well. Leslie Stephen writes that "Swift had the ... task of really striking the keynote for his party. He was to put the ministerial theory into that form in which it might seem to be the inevitable utterance of strong common-sense. ${ }^{n 38}$

The Examiner's role also included convincing a nation and a caucus that a negotiated peace, on terms favourable to both England and France, to the ongoing war with France was necessary. On one 
side, the Tories were frustrated. They had long argued for a peace at any cost (a position potentially disastrous for the English government). On the other side, the Whigs adamantly opposed any settlement, allowing Swift to claim, in the words of W. A. Speck, "the party conflict was really between lovers of peace and lovers of war." 39 The argument that the Whigs and the War were jointly responsible for taking power out of the hands of the landed gentry was so popular in the Examiner that Murry called it the "leading argument" of the entire collection ${ }^{40}$ And Swift himself claimed, "[N] othing bore [the Whigs] up but their Credit with the Bank and other Stocks, which would be neither formidable nor necessary when the War was at an End. For these Reasons they resolved to disappoint all Overtures of a Peace, until they and their Party should be so deeply rooted as to make it impossible to shake them. ${ }^{\text {"11 }}$

The Examiner's success in crystallizing Tory party policy can be measured in part by the degree to which biographers and critics of Swift have identified the Examiner's editorial policy with official Tory positions. Samuel Johnson, for instance, wrote that "In the reign of Queen Anne he turned the stream of popularity against the Whigs, and must be confessed to have dictated for a time the political opinions of the English nation." ${ }^{\text {2 }}$

An even more convincing argument for the Examiner's importance and influence is that the Tories themselves trusted Swift. One may judge Swift's success by his continuing employment by the Harley regime. When Harley first came into power, and was under a great deal of political and ideological pressure, Swift was the Tory spokesman. According to contemporary opinion, the Examiner was "the most influential and effective [journal] of its kind." ${ }^{43}$ After the Examiner had outlived its usefulness, it was Swift who was chosen to write the influential and important "The Conduct of the Allies ..." for instance, which argued eloquently for the peace the Examinerhad so long advocated.

There is considerable evidence that the Examiner was perused eagerly not only in the coffee-houses of London, but also in the areas of England dominated by the rural country squires Swift imicated so well. J.E. Mercer, for instance, records the wide distribution and use of the Examiner in rural prebends: "copies of the Examiner were treasured by the clergy and used in their parishes ..." 44 and Temple Scott, in his edition of Swift's Prose Works, quotes Churton Collins's claim that the Examiner "became a voice of power in every town and every hamlet throughout England." 


\section{Past Imperfect}

Perhaps the strongest evidence for the success of the Examinerand its strong stance against the war (which was the rallying point for the Tories of the period), is that the war ended, with popular support, less than two years after the appearance of Swift's columns. Ricardo Quintana notes: "the Examiner had been preparatory propaganda; through its columns the nation had been turned towards peace." 46

Finally, Swift himself, of course, was well pleased with what he accomplished during his reign as "the first lord of English journalists." ${ }^{77}$ He wrote:

And now I conceive the main Design I had in writing these Papers, is fully executed. A great Majority of the Nation is at Length thoroughly convinced, that the Queen proceeded with the highest Wisdom, in changing her Ministry and Parliament. That, under a former Administration, the greatest Abuses of all Kinds were committed; and the most dangerous Attempts against the Constitution for some Time intended. The whole Kingdom finds the present Persons in Power, directly and openly pursuing the true Service of their Queen and Country; and to be such whom their most bitter Enemies cannot tax with Bribery, Covetousness, Ambition, Pride, Insolence, or any pernicious Principles in Religion or Government. $^{48}$

This is obvious, direct party propaganda. It is pro-Tory and antiWhig, and neither balanced nor reasoned.

The difficulties of dealing with Swift's change in party arise in part because Swift entertained old-fashioned notions about politics when he first became the editor of the Examiner. His view of politics was inherited from Temple and then used by Harley and St. John. By 1710, to Swift's dismay, political parties began to evolve from circles of influential friends to repositories of ideology and organizations that formed party policy. This change was marked by Whig reluctance to negotiate with Swift. The Whigs insisted that he negotiate policy, not influence. The change was also signalled by the Tories' founding of the Examineras a vehicle for party propaganda, and then in their use of the paper as a platform from which to agitate for the end of the war in Europe.

Swift was prepared to change parties in 1710 because his notions of what constitured a party were old-fashioned. When he first 
became a Tory, "party" was synonymous with influence and interests. Thanks to his friendship with Harley, his best interests were served by the Tories, and not by the Whigs, who had already begun to change. By the time Swift resigned as editor of the Examiner, however, even Tory definitions of "party" had changed dramatically. Ideological position became increasingly imporeant to both British political parties. The Examiner helped to build the Tories into a political entity, out of the loosely organized circle of opposition it had been. The change was not completed in Swift's lifetime, but it was far enough advanced to prevent any further switching on his part.

Swift arrived in London as a rather naive churchman, prepared to carry on what he thought were political negotiations. He came prepared to use old friends and be used by them. Instead, he found that the Whigs were becoming part of a new political world. They were reluctant to exchange political favours for personal ones. Swift became Tory, and gloated about his mission's success to the Irish churchmen who had sent him. Before long, however, the Tory view of politics changed as well, as the Examiner hardened into a useful party forum. When Swift retired to St. Patrick's after the collapse of the Tory regime, he may have been bitter about party politics, but he certainly was never again so naive. 


\section{NOTES}

'I am indebted to the editors of this journal and several anonymous referees for their helpful comments. Parts of this paper appeared first as portions of my MA thesis ("Swift and the Problem of Power," University of Alberta, 1987).

'In feudal times, the so-called First Fruits referred to the first year's income of the Church in a given benefice. It was customary to pay this stipend to the Pope in return for the patronage that had secured the position in the first place. Under the reforms of Henry VIII, the First Fruits reverted to the Crown. In 1703-4, Queen Anne established a trust fund under which the First Fruits payments were used to augment poor church livings. The Twentieth Parts, likewise, was a traditional Papal tax of one-twentieth of the annual income of a benefice. This fund, too, had reverted to the Crown under Henry VIII, and had been remitted by Anne. The Irish Church was anxious to secure grants for itself that were equivalent to those that were accorded to the English Church. Swift's negotiations actually date as far back as 1704 and 1707. Most recently, he had been dealing with the Whig ministry of Godolphin in 1708-9. See, among others, Henry Craik's The Life of Jonathan Swift (London, 1882); J.A. Downie's Jonathan Swift, Political Writer (London, 1984); John Middleton Murry's Jonathan Swift: A Critical Biography (London, 1954); Ricardo Quintana's Swift: An Introduction (London, 1955); and Harold Williams's Introduction to his edited edition of the Journal to Stella, 1 (Oxford, 1948), xiv-xvii.

${ }^{3}$ Swift actually began the Journal to Stella with a complaint about his reception by Godolphin himself, who apparently displayed "a great deal of coldness" (Journal to Stella 1, 6). The only major exception to the Whig bias in Swift's acquaintances seems to be the Tory "duke of Ormond" (Ibid., 11).

On an earlier trip, Swift first met Whig writers Addison and Steele (Williams speculates in his notes to the Journal to Stella that the first meeting was "early in 1708" [Ibid., 12 n.8]). He actually became involved during that visit with early editions of the Tatler. During the 1710 visit, he "sat till ten in the evening [of September 10] with Addison and Steele" (Ibid., 12-13). The Journal to Stella names numerous influential Whig associates and various Whig haunts frequented by Swift in the early days of that September. Among others, Swift mentions Whigs as powerful as Somers (Ibid., 15) and 
Lord Wharton (Ibid., 10), as well as the relatively lesser known Matthew Dudley (Ibid., 11) or Benjamin Hoadly (Ibid., 16); Swift frequented "Bull's on Ludgate" (Williams calls Bull's "a Whig haberdasher" [Ibid., 16 n.20]); he spent a good deal of time in "St. James's Coffee-house" (Williams notes "The St. James's was a resort of the Whigs" [Ibid., 11 n.3]); his most frequent correspondent aside from Stella seems to have been Archbishop King, a strong Whig. ${ }^{4}$ By 12 September 12, he wrote: "I protest upon my life, I am heartily weary of this town, and wish I had never stirred" (Ibid., 16).

s Ibid., 36

"W.A. Speck, "From Principles to Practice: Swift and Party Politics," in The World of Jonathan Swift. Essays for the Tercentenary, ed. Brian Vickers (Cambridge, Mass., 1968), 69-86, at 69

${ }^{7} \mathrm{G}$. Holmes, British Politics in the Age of Anne (London, 1967), 247

${ }^{8}$ D.H. Stevens, Party Politics and English Journalism 1702-1742 (1916; reprint, New York, 1967), 36-7. Stevens is not alone. See, for instance, F.P. Lock, "Swift and English Politics, 1701-14" (The Character of Swift's Satire: A Revised Focus, ed. Claude Rawson [Newark, 1983], 127-50), William Makepeace Thackeray (The English Humourists of the Eighteenth Century [1853; reprint, London, 1904], 1-32), or J.H. Bernard's Introduction to The Correspondence of Jonathan Swift, D.D., (ed. F.E. Ball [London, 1910-14], 1, xixlvi). All quotations from Swift's correspondence are taken from this edition.

${ }^{9}$ Louis Landa, Swift and the Church of Ireland (Oxford, 1954; reprint, 1965). Swift remained bitter his whole life about what he viewed as mistreatment by prominent Tories, including Archbishop King, the Irish Archbishop primarily responsible for sending Swift to England on behalf of the Irish Church, and Bolingbroke, Henry St. John, Harley's most significant minister and advisor. As many as twenty years later, his correspondence was still bitter. On 18 May 1727, Swift wrote to Archbishop King: "your grace hath thought fit to take every opportunity of giving me all sorts of uneasiness, without ever giving me, in my whole life, one single mark of your favour, beyond common civilities... I thought, and have been told, that I deserved better from that Church and that kingdom: I am sure I do from your Grace" (Swift, Correspondence, 3, 210). On 21 March 1730, Swift wrote to Bolingbroke: "I wonder you are not ashamed to let me pine away in this kingdom [Ireland]" (Ibid., 383).

${ }^{10}$ Speck goes so far as to call this stance "the most convincing proof 


\section{Past Imperfect}

that he was not a mere place seeker" ("From Principles to Practice," 71).

11 Journal to Stella, 1, 68

${ }^{12}$ Thomas Sheridan, The Life of the Rev. Dr. Jonathan Swift, Dean of St. Patrick's, Dublin (1784; reprint, New York and London, 1974), 112-13. See also J.E. Mercer, "The Political Attitudes and Affiliations of Jonathan Swift with Particular Emphasis on his Relations with the Harley Ministry" (PhD thesis, University of Toronto, 1970) and Ricardo Quintana, Swift: An Introduction (London, 1955).

13 Journal to Stella, 1, 66

14 Jonathan Swift: A Critical Biography (London, 1954), 175. This was not true only of the Whigs, of course. Sheila Biddle points out in Bolingbroke and Harleythat "while Swift was in daily converse with the ministers, he was never fully in their confidence..." (New York, 1974, 5).

15 Journal to Stella, 1, 13

${ }^{16}$ For examples of Swift's bitterness over what he perceived to be poor treatment, see the letters to St. John and Archbishop King (cited above in note 9).

${ }^{17}$ Irvin Ehrenpreis, Swift: The Man, His Works, and the Age, 3 vols. (London and Cambridge, MA, 1962-83), 2, 252

18 Jonathan Swift, The Prose Works of Jonathan Swifh ed. Herbert Davis et al. (Oxford, 1939-68), 8, 120. All quotations from Swift's Prose Works are taken from this edition. All quotations from the Examiner are from Prose Works, 3.

19 Journal to Stella, 1, 46

${ }^{20}$ Speck, "From Principles to Practice," 80-1; see Kathleen Williams, Jonathan Swift and the Age of Compromise (Lawrence, Kansas, 1958) 21 Swift, Prose Works, 2, 25

${ }^{22}$ See J.P. Kenyon, Revolution Principles: The Politics of Party 16891720. Kenyon writes "in England conservatism was still the natural political philosophy," due in part to "the inbuilt assumptions of an age of deference" (Cambridge, 1977), 61. On the other hand, "[ $\mathrm{t}] \mathrm{he}$ Exclusion Crisis swung the church decisively behind Charles and his brother James, and added to divine right and passive obedience the dogma of hereditary succession, according to which the crown must descend in the right line by blood, even if this meant, as in this case, the accession of a Roman Catholic" (Ibid., 65). Swift may well have wished to avoid the question of party altogether, but it is equally 
obvious that such avoidance was increasingly less possible. Geoffrey Holmes notes, however, in British Politics in the Age of Anne, that on certain "ultra-partisan" ("extream"?) measures, many Tories were inclined to "part company" and "drift toward the centre" (London, 1967,) 16.

${ }^{23}$ On 2 October 1710, "Lord Halifax began a health [toast] to me to-day: it was the Resurrection of the Whigs, which I refused unless he would add their Reformation too: and I told him he was the only Whig in England I loved, or had any good opinion of' Journal to Stella, 1, 38-9. 14 October 1710: "I suppose I have said enough in this and a former letter how I stand with new people; ten times better than ever I did with the old; forty times more caressed" Ibid., 58-9. ${ }^{24}$ See Swift's caunting of his opponents - rival journalists - as "stupid illiterate Scribblers" (Examiner No. 15), or his mocking of their "scurrilities" in No. 41; he is slanderous in his treatment of Marlborough in, especially, No. 16 or No. 27. On Swift's performance in the Examiner, see Julia T. Reinemeyer, "Swift, Bolingbroke, and the Examiner. The Literary and Intellectual Quality of Political Polemics Set by Henry St. John and Jonathan Swift" (PhD thesis, New York Universiry, 1974), or Thomas Atteridge, "Knavery and Artistry Sublime: Swift's Examiner, 1710-11" (PhD thesis, Duke University, 1972). Speck calls Swift's $A$ Short Character of Thomas, Earl of Wharton, published in 1710, "one of the most savage attacks on a politician to appear in print" ("From Principles to Practice," 69). Bolingbroke himself admits that he and Swift were out to "hurt those who stood in opposition to us," and in fact wanted "to break the body of the Whigs" quored in David Green, Queen Anne (New York, 1970), 85.

${ }^{25}$ Geoffrey Holmes, British Politics in the Age of Anne, (London, 1967), 266

${ }^{26}$ Journal to Stella, 1, 1-35

${ }^{27}$ Swift, Prose Works, 5, 195

28 Journal to Stella, 1, 66

${ }^{29}$ On the original and the changing distinctions between Tory and Whig, see Holmes's British Politics in the Age of Anne, especially pages 13-50, the chapter entitled "Tory and Whig."

${ }^{30}$ J.R. Jones, in The First Whigs: The Politics of the Exclusion Crisis 1678-1683, (London, 1961) 2 notes that "The first Whigs were, and had to be, a party, something more highly organized and disciplined than a mere alliance or coalition of small and autonomous groups"; 
the necessity for the Whigs to be an organized party arose from their position in opposition (opposed to the Crown, writes Jones, and not to the Tories), "for they were never more than royal auxiliaries" Ibid., 6.

${ }^{31}$ The Tories had a convenient and ready market for their propaganda in the general public. J.A. Downie, in Robert Harley and the Press: Propaganda and Public Opinion in the Age of Swift and Defoe, paints a striking picture of the strong and growing "social need for literature" of all types; literacy was spreading quickly as a social fact, and the burgeoning political presses were scrambling to keep pace with the increasing demand for reading material. In fact, writes Downie, the growing literacy rate and the growing sense of popular political power fed off each other, until it became "virtually impossible to divorce literary and political considerations" (Cambridge, 1979), 15. See also K.B. Smellie, Great Britain Since 1688: A Modern History (Ann Arbor, Michigan, 1962), 4ff.; D.H. Stevens, Party Politics and the Age of Journalism, 29ff.; and Dorothy Marshall, Eighteenth-Century England (1962; reprint, London, 1974), 37$40 \mathrm{ff}$.

${ }^{32}$ Thomas Atteridge, "Knavery and Artistry Sublime," 32

${ }^{33}$ Richard I. Cook, Jonathan Swift as a Tory Pamphleteer (Seattle, 1967), 31

${ }^{34}$ Swift, Prose Works 3, 13.

${ }^{35}$ Kenyon, Revolution Principles, 62

${ }^{36}$ F.P. Lock, "Swift and English Politics, 1701-14," in The Character of Swift's Satire: A Revised Focus, ed. C. Rawson (London, 1983), 127-50, at 134

${ }^{37}$ According to Irvin Ehrenpreis, (Swift: The Man, His Works, and the Age 2, 58) "the Tories by tradition possessed little in the way of political theory"; D.H. Stevens (Party Politics and English Journalism 1702-1742 [1916; reprint New York, 1967], 31) actually names the Tory party "the unformed party"; and W.A. Speck (Stability and Strife: England 1714-1760 [London, 1977], 148) has called the Whigs without doubt "the more disciplined [i.e. well-organized] party" of the two.

${ }^{38}$ Leslie Stephen, Swift (1882; reprint, Detroit, 1968), 88

${ }^{39}$ W.A. Speck, Stability and Strife, 149; see also Leslie Stephen, who noces that Swift's ultimate argument is that peace is the "natural policy" of the Tories, and war the "natural fruit" of the Whigs (Swift, 89).

${ }^{40}$ Murry, Jonathan Swift: A Critical Biography, 197 
${ }^{41}$ Swift, Prose Works, 3, 63

${ }^{42}$ Lives of the English Poets, ed. George B. Hill (Oxford, 1905), 1, 50

${ }^{43}$ Cited by Atteridge "Knavery and Artistry Sublime," 129

${ }^{44}$ Mercer, "The Political Attitudes and Affiliations of Jonathan Swift," 129

${ }^{45}$ The Prose Works of Jonathan Swift, D.D., 9, ed. Temple Scott (London, 1898-1908), 69

${ }^{46}$ Quintana, The Mind and Art of Jonathan Swift, 187

${ }^{47}$ Julia Reinemeyer, "Swift, Bolingbroke, and the Examiner. The Literary and Intellectual Quality of Political Polemics Set by Henry St. John and Jonathan Swift" (PhD thesis, New York University, 1974), 1

${ }^{48}$ Swift, Prose Works, 3, 171 